\title{
BEAR AT THE BACK DOOR
}

Deur generaal sir Walter Walker KCB, CBE, DSO. Sandton. Uitgegee deur Valiant Publishers. Verskyningsdatum Julie 1978. Prys R10.)

Hierdie boek is ' $n$ uitstekende aktuele geskrif ook Suidelike Afrika se politieke en militêre aspekte wat deur 'n algehele buitestaander $\mathrm{nl}$ 'n Britse Generaal Sir Walter Walker, KCB, CBE, DSO, geskryf is. Die boek het veel hedendaagse waarde aangesien die skrywer tot so onlangs April/Mei verlede jaar nog in Suid-Afrika, Suidwes-Afrika en Rhodesië besoek afgelê het.

Die skrywer skryf met gesag oor terrorisme agv sy militêre agtergrond en ondervinding. Hy skryf ook gesaghebbend oor politieke aspekte in die RSA, SWA en Rhodesië wat hy eerstehands ingewin het tydens sy besoeke en gesprekke met verskeie politieke leiers van verskillende rassegroepe wat hy gevoer het.

Wat veral uitstaan, is die skrywer se pro-SuidAfrikaans/Rhodesiese sienswyse. Hy kom amper bevooroordeeld voor soos hy kant kies vir Suid-Afrika en Rhodesië. Dit kan moontlik toegeskryf word aan selfvergewissing agv die feitesendings wat hy hierheen onderneem het, sowel as sy militêre ondervinding en agtergrond en wêreldse kennis. Hy verwys juis na sommige van sy eie landgenote as die 'know-alls' wat in Engeland 'n groot lawaai opskop teenoor Suid-Afrika se rassebeleid, maar nog nooit vir hulleself kom kyk het nie.

Feite oor Suidwes-Afrika, Suid-Afrika en Rhodesië is absoluut korrek. Wat sy boek soveel waarde gee, is die verskeie persoonlike onderhoude wat hy met politieke leiers, wit, swart en bruin in Suid-Afrika gevoer het asook sy persoonlike betrokkenheid met die SAW gedurende sy tweede besoek. Dieselfde geld ook vir sy besoek aan Rhodesië.

Hierdie boek gee 'n helderder insig in politieke en militêre aspekte in Suid-Afrika en Rhodesië. Daar word duidelik gesien hoe die huidige SA Regering besig is om weg te beweeg van rassediskriminasie, veral die sg 'Petty Apartheid' en hoe die ander rassegroepe aandring op 'n nuwe bedeling in die politieke opset van die land. Daar word ook heelwat geskryf oor die Rhodesiese 'Binnelandse Skikking' en oor die voornemende 'Swart meerderheidsregering' in daardie land. Die skrywer verwys ook na die drie gematigde swart politieke leiers en sy persoonlike onderhoud met Eerw Ndabaningi Sithole. Die terroriste organisasies van Joshua Nkomo en Robert Mugabe word ook bespreek en hoe die Kommuniste hulle beïnvloed en gebruik.

Die alomteenwoordige kommunistiese bedreiging, wat op die oog af binne bepaalde situasies, nie as sodanig ervaar word nie, word uitgelig binne die raamwerk van wêreldgebeure.

Benewens die valse belottes en hoop wat op aktiewe wyse aan goedgelowiges voorgehou word hier te lande, word die strewe na persoonlike mag en populariteit ook aangewend om die uiteindelike kommunistiese ideologie wêreldwyd te versprei. In die VSA bv neem hierdie werwing onrusbarende afmetings aan onder regeringskandidate wat ter beveiliging van hul verkiesings hierdie 'paai en beloftes politiek' sonder berekening van gevolge deurvoer.

Die boek het definitiewe inligtingswaarde, want die skrywer stip duidelik die gevaar aan wat Russiese ekspansionisme in Afrika en veral Suidelike Afrika vir die Westerse voortbestaan inhou.

(C. Prinsloo) 